\title{
PERBANDINGAN PROFIL BERTANYA SISWA DENGAN MENGGUNAKAN MODEL QUICK ON THE DRAW DAN MODEL PICTURE AND PICTURE PADA SUB MATERI EKOSISTEM \\ (Penelitian Deskriptif pada Siswa KelasVII SMP N 3 Pangandaran)
}

\author{
Nina Novia, Idad Suhada, Sumiyati Saádah \\ Pada Program Studi Pendidikan Biologi Jurusan Pendidikan MIPA Fakultas Tarbiyahdan \\ Keguruan Universitas Islam Negeri Sunan Gunung Djati Bandung
}

\begin{abstract}
ABSTRAK
Penelitian ini berawal dari observasi di SMPN 3 Pangandaran yang memperoleh data bahwa kemampuan bertanya siswa kelas VII masih kurang. Menggunakan model quick on the draw dan model picture and picture karena model pembelajaran ini mempunyai kelebihan mampu membantu siswa dalam meningkatkan kemampuan bertanya melalui gambar yang akan membantu siswa untuk mendapatkan pertanyaan.Tujuan penelitian ini adalah untuk mengetahui keterlaksanaan pembelajaran, menganalisis pertanyaan siswa melalui model quick on the draw dan model picture and picture pada sub materi ekosistem.Metode yang digunakan dalam penelitian ini adalah Deskriptif. Penelitian dilaksanakan di kelas VII SMPN 3 Pangandaran.Instrument yang digunakan berupa lembar observasi untuk mencatat pertanyaan - pertanyaan yang diajukan oleh siswa.Hasil analisis observasi aktivitas pembelajaran guru dengan menggunakan model quick on the draw mendapat nilai rata - rata 9,07\% sedangkan dengan menggunakan model picture and picture mendapatkan nilai 92,7\% dan aktivitas pembelajaran siswa dengan menggunakan model quick on the draw mendapat nilai rata - rata $81,7 \%$ sedangkan dengan model picture and picture $87 \%$. Pertanyaan siswa secara tertulis dengan model quick on the draw menunjukan presentase $\mathrm{C} 1: 30,97 \%, \mathrm{C} 2$ : 55,76\%, C3: 13,25\%,C4: 0\% sedangkan dengan model picture and picture menunjukkan presentase C1: 33,51\%, C2: 53,07\%, C3: 13,40\%, dan C4: 0\%. Dan berdasarkan pertanyaan tertutup dan terbuka dengan menggunakan model quick on the draw memperoleh terbuka $61,95 \%$ tertutup $38,04 \%$, sedangkan dengan model picture and picture terbuka $56,98 \%$ tertutup $43,01 \%$. Jadi pertanyaan yang paling banyak muncul yaitu pada jenjang kognitif C2 (pemahaman). Dan perbandingan dilihat dari banyaknya soal yaitu lebih banyak pada model Picture and Picture.
\end{abstract}

\section{Kata Kunci: Profil Bertanya Siswa, Model Quick On The Draw dan Model Picture And Picture, Ekosistem.}

\section{PENDAHULUAN}

Pendidikan merupakan peranan penting yang terdapat dalam suatu bangsa.Berhasil atau tidaknya suatu bangsa dapat dilihat dari pendidikan warga negaranya. Pendidikan di Indonesia masih tergolong lemah, hal ini dikarenakan masih lemahnya proses pembelajaran yang dilaksanakan. Proses pembelajaran di dalam kelas lebih cenderung diarahkan untuk menghafal suatu informasi, tidak memahami informasi itu untuk dihubungkan dengan kehidupan sehari-hari. Siswa tidak berpikir bahwa pembelajaran biologi di kelas akan mempunyai suatu hubungan yang erat dengan kehidupan sehari-hari. Selain itu kurangnya minat dan kesungguhan siswa dalam belajar biologi karena kurangnya pandangan pentingnya biologi dalam kehidupan sehari-hari, menjadikan sikap negatif timbul dalam diri siswa. Bentuk sikap negatif inilah yang menjadi 
katalisator keberhasilan siswa dalam pembelajaran biologi.Hal ini dapat dikatakan bahwa kemampuan disposisi biologisnya masih kurang. Sehingga perlunya ditumbuhkan sikap positif serta kebiasaan untuk melihat biologi sebagai sesuatu yang berguna dalam kehidupan sehari-hari (Syaban, 2009:129).

Tiap-tiap sesuatu yang merupakan kegiatan tentunya mempunyai suatu fungsi dan tujuan yang hendak dicapai, tidak terkecuali kegiatan yang menyangkut pendidikan. Adapun fungsi dan tujuan pendidikan yang tertera dalam undangundang Sistem Pendidikan Nasional (SISDIKNAS) nomor 20 Tahun 2003 Bab II pasal 3 ayat 1 tentang Dasar Fungsi dan Tujuan menyebutkan bahwa:

Pendidikan nasional berfungsi mengembangkan kemampuan dan membentuk watak serta peradaban bangsa yang bermartabat dalam rangka mencerdaskan kehidupan bangsa, bertujuan untuk berkembangnya potensi peserta didik agar menjadi manusia beriman dan bertakwa kepada Tuhan Yang Maha Esa, berakhlak mulia, sehat, cakap, kreatif, mandiri, dan menjadi warga Negara yang demokratis serta bertanggung jawab.

Bertanya dalam kelas adalah aktivitas yang sangat penting dalam proses belajar mengajar, seperti pepatah mengatakan malu bertanya sesat dijalan. Artinya apabila siswa malu bertanya pada saat pembelajaran makan bisa salah konsep dalam mengerjakan soal.Hasibuan, dkk. (2008:14) menyatakan bahwa dalam proses belajar mengajar bertanya memegang peranan yang penting. Oleh karena itu, seseorang yang melakukan kegiatan bertanya termasuk dalam golongan orang yang melakukan proses berpikir, proses berpikir inilah yang mengakibatkan anak melakukan proses belajar. Telah banyak ditemukan bahwa kualitas pembelajaran akan meningkat jika peserta didik pada proses pembelajaran memperoleh kesempatan yang luas untuk bertanya, berdiskusi, dan menggunakan secara aktif pengetahuan yang baru diperoleh (Sudarman 2009 : 67).

Ginnis (2008:11) mengemukakan, Quick On The Draw merupakan sebuah aktivitas untuk kerja tim dan kecepatan yang dapat mendorong kerja kelompok. Aktivitas ini berupa pacuan antar kelompok yang bertujuan mencari kelompok pertama yang dapat menyelesaikan satu set pertanyaan. Untuk menjadi kelompok pemenang atau kelompok pertama yang dapat menyelesaikan satu set pertanyaan dalam waktu paling singkat, maka perlu adanya saling ketergantungan positif dan komunikasi yang baik antar anggota kelompok. Setiap anggota kelompok juga harus aktif, bertanggung jawab pada tugas masing-masing, saling bekerjasama, dan perlu adanya sikap disiplin menuju tercapainya keberhasilan kelompok.

Hamdani (2010:89), "Model picture and picture adalah suatu model belajar yang menggunakan gambar yang dipasangkan atau diurutkan menjadi urutan logis." Media gambar yang digunakan dalam menjelaskan materi yang di ajarkan dengan tujuan agar siswa lebih aktif dalam belajar.Dengan menggunakan media gambar, diharapkan siswa mampu mengikuti pelajaran dengan fokus sehingga apapun pesan yang disampaikan bisa diterima dengan baik dan dapat diingat kembali oleh siswa. Gambar-gambar ini menjadi faktor utama dalam proses pembelajaran. sehingga sebelum proses pembelajaran guru sudah menyiapkan gambar yang akan ditampilkan.Pembelajaran ini memiliki ciri Aktif, Inovatif, Kreatif, dan Menyenangkan. Model apapun yang digunakan selalu menekankan aktifnya peserta didik dalam setiap proses pembelajaran.

Berdasarkan latar belakang di atas maka di buat rumusan masalah sebagai berikut:

1. Bagaimana keterlaksanaan pembelajaran dengan menggunakan Model quick on the draw danModel 
picture and picture pada materi pokok ekosistem?

2. Bagaimanakah jenjang pertanyaan kognitif yang paling banyak muncul dalam pertanyaan siswa pada materi ekosistem melalui pembelajaran dengan Model quick on the draw dan Model picture and picture?

3. Bagaimana sifat pertanyaan yang lebih banyak muncul, pertanyaan terbuka atau pertanyaan tertutup?

\section{METODE PENELITIAN}

Tujuan dari penelitian ini adalah sebagai berikut :

1. Untuk mendeskripsikan keterlaksanaan pembelajaran dengan menggunakan Modelquick on the drawdan Modelpicture and picturepada materi pokok ekosistem.

2. Untuk menganalisis jenjang pertanyaan Kognitif yang paling banyak muncul dalam pertanyaan siswa pada materi ekosistem melalui pembelajaran dengan Model quick on the drawdan Model picture and picture.

3. Untuk menganalisis sifat pertanyaan yang lebih banyak muncul, pertanyaan terbuka atau pertanyaan tertutup.

Hasil penelitian merupakan rekapitulasi dari analisis data dengan mengacu pada rumusan masalah yang terdapat pada bab I. Rumusan masalah tersebut yaitu mendeskripsikan keterlaksanaan proses pembelajaran dengan menggunakan model quick on the draw dan model picture and picture pada sub materi ekosistem, analisis kemampuan bertanya siswa berdasarkan jenjang kognitif taksonomi Bloom dengan menggunakan model quick on the draw dan model picture and picture pada submateri ekosistem,analisis kemampuan bertanya siswa berdasarkan sifat pertanyaan dengan menggunakan model quick on the draw dan model picture and picture pada sub materi ekosistem.

\section{Keterlaksanaan Pembelajaran}

Jawaban untuk rumusan masalah pertama diperoleh dari hasil analisis lembarobservasi. Jumlah observer pada penelitian ini berjumlah satu orang dan observasi dilaksanakan saat berlangsungnya proses belajar mengajar di kelas. Objek observasi dalam penelitian ini adalah aktivitas guru dan aktivitas siswa selama kegiatan belajar mengajar. Hasil observasi aktivitas guru kelasdituangkan dalam Tabel 1 dan 2 sebagai berikut :

Tabel 1. Hasil Observasi Aktivitas GuruDengan Model Quick On The Draw

\begin{tabular}{|c|c|c|c|}
\hline \multirow{2}{*}{ No } & \multirow{2}{*}{ Tahapan } & \multicolumn{2}{|c|}{ Keterlaksanaan (\%) } \\
\hline & & Guru & Interpretas \\
\hline 1 & $\begin{array}{l}\text { Pertemuan ke- } \\
1\end{array}$ & $80 \%$ & Baik \\
\hline 2 & $\begin{array}{l}\text { Pertemuan ke- } \\
2\end{array}$ & $90 \%$ & $\begin{array}{l}\text { Sangat } \\
\text { Baik }\end{array}$ \\
\hline 3 & $\begin{array}{l}\text { Pertemuan ke- } \\
3\end{array}$ & $100 \%$ & $\begin{array}{l}\text { Sangat } \\
\text { Baik }\end{array}$ \\
\hline & Rata-rata & $90 \%$ & $\begin{array}{l}\text { Sangat } \\
\text { Baik }\end{array}$ \\
\hline
\end{tabular}

(Sumber : Lampiran C1)

Tabel 2. Hasil Observasi Aktivitas

GuruDengan Model Picture and Picture

\begin{tabular}{|c|c|c|c|}
\hline \multirow{2}{*}{ No } & \multirow{2}{*}{ Tahapan } & \multicolumn{2}{|c|}{ Keterlaksanaan (\%) } \\
\hline & & Guru & Interpretasi \\
\hline 1 & $\begin{array}{l}\text { Pertemuan ke- } \\
1\end{array}$ & $83 \%$ & Baik \\
\hline 2 & $\begin{array}{l}\text { Pertemuan ke- } \\
2\end{array}$ & $95 \%$ & Sangat Baik \\
\hline 3 & $\begin{array}{l}\text { Pertemuan ke- } \\
3\end{array}$ & $100 \%$ & Sangat Baik \\
\hline & Rata-rata & $92,7 \%$ & $\begin{array}{l}\text { Sangat } \\
\text { Baik }\end{array}$ \\
\hline
\end{tabular}

Dari Tabel 1.diatas diperoleh data bahwa keterlaksanaan proses dengan menggunakan model quick on the drawmemiliki persentase $90 \%$ dengan kriteriasangat baik. Table 2.diatas diperoleh data bahwa keterlaksanaan proses dengan menggunakan model picture and picturememiliki persentase $92,7 \%$ dengan kriteriasangat baik. Dapat disimpulkan bahwa keterlaksanaan 
aktivitas guru dalam kegiatan belajar mengajar dikelas terlaksanadengan ketegori sangat baik.

Untuk memperkuat data keterlaksanaan proses pembelajaran maka aktivitas siswa ketika belajar di kelas juga menjadi objek observasi. Hasil observasi aktivitas siswa dituangkan dalam Tabel 3.dan 4.sebagai berikut :

Tabel 3. Hasil Observasi Aktivitas Siswa Dengan Model quick on the draw

\begin{tabular}{cccl}
\hline \multirow{2}{*}{ No } & \multirow{2}{*}{ Tahapan } & \multicolumn{2}{c}{ Keterlaksanaan (\%) } \\
& & Siswa & Interpretasi \\
\hline 1 & Pertemuan ke-1 & $75 \%$ & cukup \\
2 & Pertemuan ke-2 & $80 \%$ & Baik \\
3 & Pertemuan ke-3 & $90 \%$ & Baik \\
\hline & Rata-rata & $81,7 \%$ & Baik \\
\hline
\end{tabular}

(Sumber : Lampiran C1)

Tabel 4. Hasil Observasi Aktivitas Siswa Dengan Model Picture and Picture

\begin{tabular}{cccl}
\hline \multirow{2}{*}{ No } & \multirow{2}{*}{ Tahapan } & \multicolumn{2}{c}{ Keterlaksanaan (\%) } \\
& & Siswa & Interpretasi \\
\hline 1 & Pertemuan ke-1 & $75 \%$ & Cukup \\
2 & Pertemuan ke-2 & $88 \%$ & Baik \\
3 & Pertemuan ke-3 & $98 \%$ & Baik \\
\hline & Rata-rata & $87 \%$ & Baik \\
\hline
\end{tabular}

(Sumber : Lampiran C1)

Berdasarkan Tabel 3.dapat dilihat bahwa rata-rata persentase aktivitas siswa dengan menggunakan model quick on the draw memperoleh persentase sebesar $81,7 \%$ dengan kriteriabaik dan Tabel 3 . dapat dilihat bahwa rata-rata persentase aktivitas siswa dengan menggunakan model picture and picture memperoleh persentase sebesar $87 \%$ dengan kriteriabaik. Dari data tersebut dapat disimpulkan bahwa keterlaksanaan aktivitas siswa dalam proses belajar mengajar di kelas di kriteriakan baik.

Presentase aktivitas guru dan siswa dapat diketahui bahwa keterlaksanaan proses pembelajaran pada setiap pertemuannya mengalami peningkatan. Pada pertemuan kesatu aktivitas guru secara keseluruhan terlaksana dengan baik.Akan tetapi, guru masih perlu penyesuaian terhadap siswa dan lingkungan karena baru pertama kali
bertemu.Adapun untuk keterlaksanaan aktivitas siswa masih belum paham terhadap teknikpembelajaran tidak sepenuhnya terlaksana. Adapun Pada pertemuan kedua guru sudah bisa mengelola waktu dengan baik sehingga proses pembelajaran berjalan dengan lancar. Begitu pula dengan siswa, siswa sudah mulai mengenal teknik pembelajaran menggunakan model quick on the draw dan model picture and picture.Pada pertemuan ketiga proses pembelajaran antara guru dan siswa sudah terlaksana dengan baik dan menunjukan proses belajar yang kondusif.

\section{Bertanya Termasuk Kedalam Teori Behavioristik}

Teori belajar behavioristik menjelaskan belajar itu adalah perubahan perilaku yang dapat diamati, diukur dan dinilai secara konkret.Perubahan terjadi melalui rangsangan (stimulans) yang menimbulkan hubungan perilaku reaktif (respon) berdasarkan hukum-hukum mekanistik. Stimulans tidak lain adalah lingkungan belajar anak, baik yang internal maupun eksternal yang menjadi penyebab belajar. Sedangkan respons adalah akibat atau dampak, berupa reaksi fisik terhadap stimulans.Belajar berarti penguatan ikatan, asosiasi, sifat dan kecenderungan perilaku. Teori behaviorisme sangat menekankan perilaku atau tingkah laku yang dapat di amati. Teori-teori dalam rumpun ini sangat bersifat molekular, karena memandang kehidupan individu terdiri atas unsur-unsur seperti halnya molekul-moleku.

a. Jumlah pertanyaan

Dari hasil penelitian perbandingan profil bertanya siswa dengan menggunakan model quick on the draw dan model picture and picture pada sub materi ekosistem. Untuk pertanyaan tertulis siswa ditugaskan untuk membuat pertanyaan minimal 5 pertanyaan pada setiap pertemuan diakhir pembelajaran. Namun tidak semua siswa pada setiap pertemuan mengajukkan lima pertanyaan. Jumlah seluruh pertanyaan setiap pertemuan dapat dilihat pada Tabel 5.dan 6.dibawah ini. 
Tabel 5.Jumlah Pertanyaan Setiap Pertemuan Dengan Menggunakan Model Quick On The Draw

\begin{tabular}{|c|c|c|}
\hline No & Tahapan & $\begin{array}{c}\text { Jumlah } \\
\text { Pertanyaan } \\
\text { Tertulis } \\
\end{array}$ \\
\hline 1 & $\begin{array}{l}\text { Pertemuan } \\
\text { ke-1 }\end{array}$ & 271 \\
\hline 2 & $\begin{array}{l}\text { Pertemuan } \\
\text { ke-2 }\end{array}$ & 306 \\
\hline 3 & $\begin{array}{l}\text { Pertemuan } \\
\text { ke-3 }\end{array}$ & 230 \\
\hline & Jumlah & 807 \\
\hline
\end{tabular}

Table 6. Jumlah Pertanyaan Setiap Pertemuan Dengan Menggunakan Model Picture and Picture

\begin{tabular}{llc}
\hline No & \multicolumn{1}{c}{ Tahapan } & $\begin{array}{c}\text { Jumlah Pertanyaan } \\
\text { Tertulis }\end{array}$ \\
\hline 1 & $\begin{array}{l}\text { Pertemuan ke- } \\
1\end{array}$ & 235 \\
2 & $\begin{array}{l}\text { Pertemuan ke- } \\
2 \\
3\end{array}$ & $\begin{array}{l}\text { Pertemuan ke- } \\
3\end{array}$ \\
\hline \multicolumn{3}{l}{ Jumlah } \\
\hline \multicolumn{3}{l}{ (Sumber : Lampiran C5) } \\
\end{tabular}

Berdasarkan Tabel 5. dan 6.di atas diketahui bahwa pada pertemuan pertama dengan menggunakan model quick on the draw jumlah pertanyaan siswa yang terjaring pada Table 5.sebanyak 271 pertanyaan, pada pertemuan kedua sebanyak 306 pertanyaan dan pada pertemuan ketiga sebanyak 230 pertanyaan. Jadi jumlah seluruh pertanyaan tertulis siswa sebanyak 807 pertanyaan. Sedangkan pertanyaan dengan menggunakan model picture and picture pada pertemuan pertama pertanyaan siswa yang terjaring pada Table 6.sebanyak 235 pertanyaan, pada pertemuan kedua sebanyak 409 pertanyaan, dan pada pertemuan ketiga sebanyak 251 pertanyaan. Jadi jumlah seluruh pertanyaan tertulis siswa sebanyak 895 pertanyaan.

b. Jenis Pertanyaan

Dari seluruh pertanyaan yang terjaring, pertanyaan tersebut diklasifikasikan kedalam jenis pertanyaan berdasarkan jenjang kognitif taksonomi Bloom. Selain dikelompokkan berdasarkan jenjang kognitif taksonomi Bloom, pertanyaan-pertanyaan tersebut dikelompokkan berdasarkan sifat pertanyaannya yang meliputi pertanyaan terbuka (divergen) atau pertanyaan tertutup (konvergen).

Jawaban untuk rumusan masalah kedua berupa klasifikasi pertanyaan berdasarkan jenjang kognitif taksonomi Bloom. Dari seluruh pertanyaan yang dibuat siswa, dilakukan pengelompokkan berdasarkan jenjang pertanyaan kognitif taksonomi Bloom edisi revisi yang meliputi dimensi proses kognitif yaitu jenjang pertanyaan kognitif $\mathrm{C} 1$ (menghafal), $\mathrm{C} 2$ (memahami), $\mathrm{C} 3$ (mengaplikasikan), C4 (menganalisis). Serta dilakukan pengelempokan berdasarkan sifatnya yang meliputi pertanyaan terbuka (divergen) dan pertanyaan tertutup (konvergen). Penyebaran seluruh pertanyaan siswa dari pertemuan pertama, kedua dan ketiga pertanyaan tertulis berdasarkan jenjang kognitif dan sifatnya dapat dilihat pada Tabel 7. dibawal ini.

Tabel 7.Distribusi Pertanyaan Siswa Yang Dikelompokan Berdasarkan Jenjang Pertanyaan Dimensi Proses Kognitif Taksonomi Bloom menggunakan model quick on the draw.

\begin{tabular}{cccc}
\hline No & $\begin{array}{c}\text { Jenjang } \\
\text { Kognitif }\end{array}$ & Tertulis & Persentase \\
1 & C1 & 250 & $30,97 \%$ \\
2 & C 2 & 450 & $55,76 \%$ \\
3 & C 3 & 107 & $13,25 \%$ \\
4 & C 4 & 0 & $0,00 \%$ \\
\hline \multicolumn{2}{c}{ Jumlah } & $\mathbf{8 0 7}$ \\
\hline
\end{tabular}

(Sumber : Lampiran C3)

Tabel 8.Distribusi Pertanyaan Siswa Yang Dikelompokan Berdasarkan Jenjang Pertanyaan Dimensi Proses Kognitif Taksonomi Bloom menggunakan model picture and picture. 


\begin{tabular}{cccc}
\hline No & $\begin{array}{c}\text { Jenjang } \\
\text { Kognitif }\end{array}$ & Tertulis & Persentase \\
\hline 1 & C1 & 300 & $33,51 \%$ \\
2 & C2 & 475 & $53,07 \%$ \\
3 & C 3 & 120 & $13,40 \%$ \\
4 & C4 & 0 & $0,00 \%$ \\
\hline & Jumlah & \multicolumn{2}{c}{895} \\
\hline
\end{tabular}

(Sumber : Lampiran C3)

Berdasarkan Tabel 7.dengan menggunakan model quick on the draw di atas diketahui bahwa dari 807 pertanyaan yang terdiri dari 807 tertulis, setelah dikelompokan berdasarkan jenjang pertanyaan kognitif taksonomi Bloom dan sifatnya. Dari 807 pertanyaan tertulis yang dibuat siswa yang termasuk kedalam jenis pertanyaan C1 (menghafal) yaitu sebesar 30,97\%. Pertanyaan C2 (memahami) sebesar $\quad 55,76 \%$. PertanyaanC3 (mengaplikasikan) sebesar $13,25 \%$ dan pertanyaan $\mathrm{C} 4$ (menganalisis) $0,00 \%$ atau tidak ada yang mengajukan pertanyaan pada jenjang kognitif ini. Dan pada Tabel 3.9 dengan menggunakan model picture and picture di atas diketahui bahwa dari 895 pertanyaan yang terdiri dari 895 pertanyaan tertulis, setelah dikelompokan berdasarkan jenjang pertanyaan kognitif taksonomi Bloom dan sifatnya. Dari 895 pertanyaan tertulis yang dibuat siswa yang termasuk kedalam jenis pertanyaan $\mathrm{C} 1$ (menghafal) yaitu sebesar 33,51\%. Pertanyaan C2 (memahami) sebesar 53,07\%. PertanyaanC3 (mengaplikasikan) sebesar $13,40 \%$ dan pertanyaan $\mathrm{C} 4$ (menganalisis) $0,00 \%$ atau tidak ada yang mengajukan pertanyaan pada jenjang kognitif ini. Untuk mengetahui contoh pertanyaan yang dibuat siswa secara tertulis berdasarkan jenjang kognitif taksonomi Bloom dapat dilihat pada Tabel 9.di bawah ini.

Tabel 9. Contoh Pertanyaan Yang Dibuat Siswa Secara Tertulis Dengan Menggunakan Model Quick On The Draw

\begin{tabular}{cccl}
\hline No & $\begin{array}{c}\text { Kode } \\
\text { Siswa }\end{array}$ & $\begin{array}{c}\text { Jenjang Kognitif } \\
\text { Taksonomi } \\
\text { Bloom }\end{array}$ & $\begin{array}{c}\text { Contoh } \\
\text { Pertanyaan }\end{array}$ \\
\hline 1 & S5 & C1 (menghafal) & $\begin{array}{l}\text { Apa yang } \\
\text { dimaksud } \\
\text { dengan } \\
\text { ekosistem? } \\
\text { Jelaskan } \\
\text { perbedaan } \\
\text { komunitas } \\
\text { dengan } \\
\text { populasi! } \\
\text { Bagaimana } \\
\text { urutan tingkat } \\
\text { organisasi } \\
\text { ekosistem! }\end{array}$ \\
2 & S22 & C2 (memahami) & \\
\hline & S4 & $\begin{array}{l}\text { C3 } \\
\text { (mengaplikasikan) }\end{array}$ & \\
\hline & & C4 (menganalisis) & \\
\hline
\end{tabular}

(Sumber: Lampiran C4)

Tabel 10. Contoh Pertanyaan Yang Dibuat Siswa Secara Tertulis Dengan Menggunakan Model Picture and Picture

\begin{tabular}{cccl}
\hline $\begin{array}{c}\text { N } \\
\mathbf{0}\end{array}$ & $\begin{array}{c}\text { Kode } \\
\text { Sisw } \\
\mathbf{a}\end{array}$ & $\begin{array}{c}\text { Jenjang Kognitif } \\
\text { Taksonomi } \\
\text { Bloom }\end{array}$ & $\begin{array}{c}\text { Contoh } \\
\text { Pertanyaan }\end{array}$ \\
\hline 1 & S4 & C1 (menghafal) & $\begin{array}{l}\text { Apa yang } \\
\text { dimaksud } \\
\text { dengan } \\
\text { populasi? } \\
\text { Mengapa terjadi } \\
\text { saling } \\
\text { ketergantungan } \\
\text { ? } \\
\text { Bagaimana } \\
\text { urutan rantai } \\
\text { makanan dan } \\
\text { jaring }- \text { jaring } \\
\text { makanan! }\end{array}$ \\
& S21 & C2 (memahami) & C3 \\
& & S6 & (mengaplikasikan
\end{tabular}

$4 \quad-\quad \mathrm{C} 4$ (menganalisis)

Penyebaran pertanyaan yang dibuat siswa secara tertulis dengan menggunakan model quick on the draw dan model Picture and Picture tersebar pada C1, C2 dan C3. Untuk lebih jelasnya melihat persentase dominasi jenjang pertanyaan dimensi proses kognitif taksonomi Bloom yang muncul dapat dilihat pada Gambar 3.1 dan Gambar 3.2 di bawah ini : 


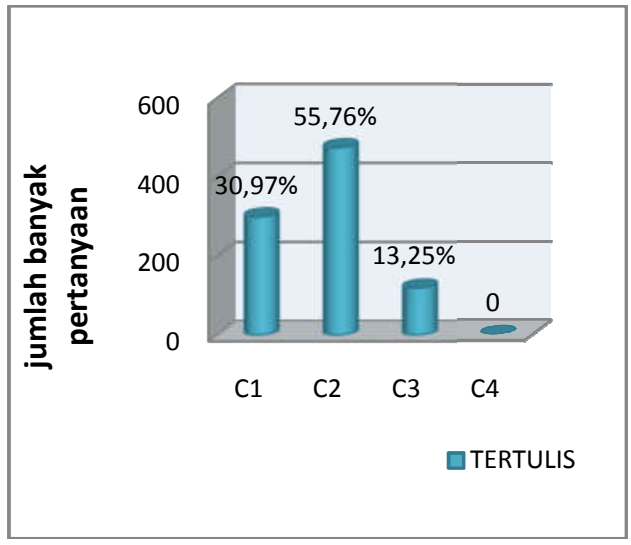

Gambar 1.Diagram Batang Pertanyaan

Siswa Berdasarkan Jenjang Pertanyaaan Dimensi Proses Kognitif Taksonomi Bloom Dengan Menggunakan Model Quick On The Draw

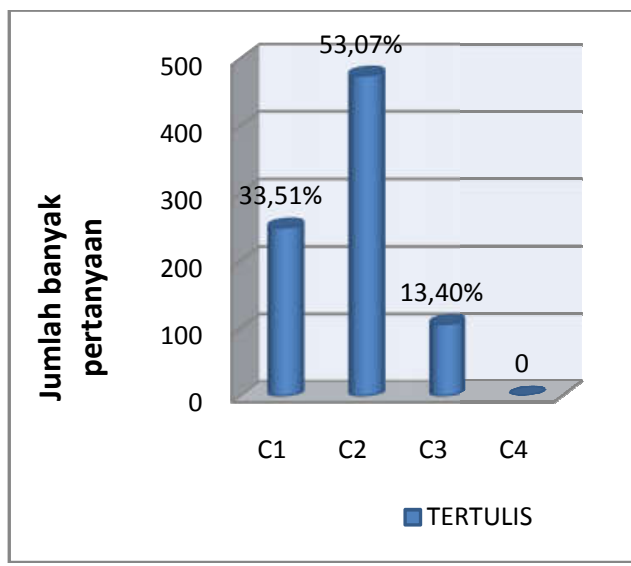

Gambar 2.Diagram Batang Pertanyaan

Siswa Berdasarkan Jenjang Pertanyaaan

Dimensi Proses Kognitif Taksonomi

Bloom Dengan Menggunakan Model Picture and Picture

Jawaban untuk rumusan masalah ketiga diperoleh berdasarkan pengelompokan sifat pertanyaan, dari pertanyaan-pertanyaan siswa yang terkumpul baik secara tertulis maupun lisan dapat dilihat pada Tabel 3.8 di bawah ini :

Tabel 11.Distribusi Pertanyaan Siswa Yang Dikelompokan Berdasarkan Sifat Pertanyaan Dengan Menggunakan Model Quick On The Draw

\begin{tabular}{clcc}
\hline No & $\begin{array}{l}\text { Sifat } \\
\text { Pertanyaan }\end{array}$ & Tertulis & Persentase \\
\hline 1 & $\begin{array}{l}\text { Terbuka } \\
\text { (divergen) } \\
2\end{array}$ & 500 & $61,95 \%$ \\
& $\begin{array}{l}\text { Tertutup } \\
\text { (konvergen) }\end{array}$ & 307 & $38,04 \%$ \\
\hline \multirow{3}{*}{ Jumlah } & $\mathbf{8 0 7}$ \\
\hline & (Sumber : Lampiran C5)
\end{tabular}

Tabel 12.Distribusi Pertanyaan Siswa Yang Dikelompokan Berdasarkan Sifat Pertanyaan Dengan Menggunakan Model Picture and Picture

\begin{tabular}{clcc}
\hline No & \multicolumn{1}{c}{$\begin{array}{c}\text { Sifat } \\
\text { Pertanyaan }\end{array}$} & Tertulis & Persentase \\
\hline 1 & $\begin{array}{l}\text { Terbuka } \\
\text { (divergen) } \\
\text { Tertutup } \\
\text { (konvergen) }\end{array}$ & 510 & $56,98 \%$ \\
\hline \multirow{3}{*}{ Jumlah } & $385,01 \%$ \\
\hline & $\mathbf{8 9 5}$ \\
\hline
\end{tabular}

Berdasarkan sifat pertanyaan terbuka atau tertutup. Dari Tabel 11.dan Table 12.diatas dapat diketahui bahwa pertanyaan tertulis yang bersifat terbuka dengan menggunakan model quick on the draw sebesar $61,95 \%$ dan pertanyaan tertutup sebesar 38,04\%. Sedangkan pertanyaan tertulis yang bersifat terbuka dengan menggunakan model picture and picture sebesar $56,98 \%$ dan pertanyaan tertutup sebesar 43,01\%. Untuk mengetahui contoh pertanyaan tertulis siswa berdasarkan sifat pertanyaannya dapat dilihat pada Tabel 13.di bawah ini.

Tabel 13. Contoh Sifat Pertanyaan Yang Dibuat Siswa Secara Tertulis Dengan Menggunakan Model Quick On The Draw

\begin{tabular}{ccll}
\hline No & $\begin{array}{c}\text { Kode } \\
\text { Siswa }\end{array}$ & $\begin{array}{c}\text { Sifat } \\
\text { Pertanyaan }\end{array}$ & Contoh Pertanyaan \\
\hline 1 & S5 & $\begin{array}{l}\text { Terbuka } \\
\text { (divergen) }\end{array}$ & $\begin{array}{l}\text { Bagaimana menjaga } \\
\text { ekosistem? }\end{array}$ \\
& & Sertutup & $\begin{array}{l}\text { Ada berapa macam } \\
\text { komponen penyusun } \\
\text { ekosistem? }\end{array}$ \\
\hline
\end{tabular}

(Sumber : Lampiran C3) 
Tabel 14. Contoh Sifat Pertanyaan Yang Dibuat Siswa Secara Tertulis Dengan Menggunakan Model Picture and Picture

\begin{tabular}{ccll}
\hline No & $\begin{array}{c}\text { Kode } \\
\text { Siswa }\end{array}$ & $\begin{array}{c}\text { Sifat } \\
\text { Pertanyaan }\end{array}$ & \multicolumn{1}{c}{$\begin{array}{c}\text { Contoh } \\
\text { Pertanyaan }\end{array}$} \\
\hline 1 & S5 & $\begin{array}{l}\text { Terbuka } \\
\text { (divergen) }\end{array}$ & $\begin{array}{l}\text { Bagaimana menjaga } \\
\text { keseimbangan } \\
\text { ekosistem? } \\
\text { Ada berapa macam }\end{array}$ \\
2 & S8 & $\begin{array}{l}\text { Tertutup } \\
\text { (konvergen) }\end{array}$ & $\begin{array}{l}\text { komponen penyusun } \\
\text { kosistem? }\end{array}$ \\
\hline
\end{tabular}

(Sumber : Lampiran C3)

Pada pertanyaan tertulis siswa yang dominan muncul adalah pertanyaan yang bersifat terbuka (divergen). Secara jelasnya untuk melihat persentase kemunculan sifat pertanyaan terbuka atau tertutup pada pertanyaan tertulis dapat dilihat pada Gambar di bawah ini :

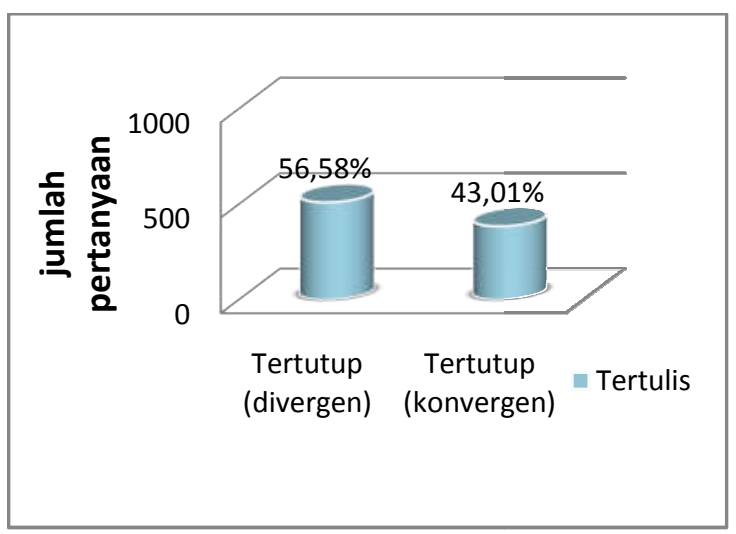

Gambar 3.Diagram Batang Pertanyaan Siswa Berdasarkan Sifat Pertanyaan Dengan Menggunakan Model Quick On The Draw

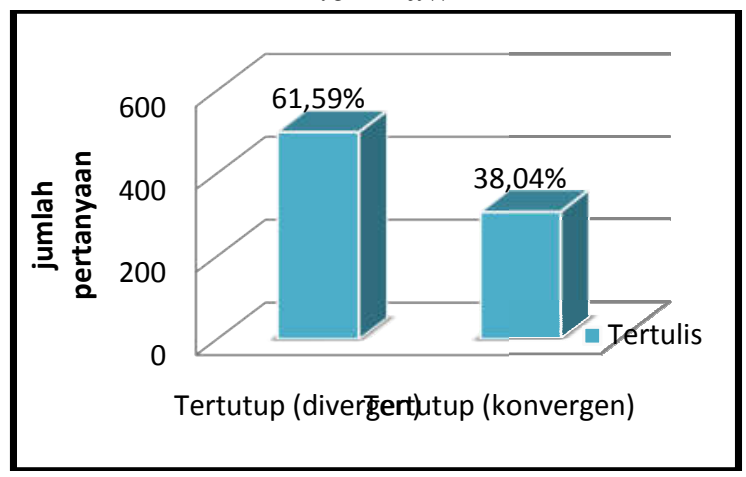

Gambar 4.Diagram Batang

Pertanyaan Siswa Berdasarkan Sifat Pertanyaan Dengan Menggunakan Model Picture and Picture

\section{PEMBAHASAN}

1. Keterlaksanaan Proses Pembelajaran Dengan Menggunakan Model Quick On The Draw Dan Model Picture And Picture

Untuk melihat keterlaksanaan proses pembelajaran dilakukan pengamatan mengenai aktivitas guru dan siswa pada setiap tahapan pembelajaran. Dalam pembelajaran dengandengan menggunakan model quick on the draw dan model picture and picturedilakukan penilaian keterlaksanaan proses pembelajaran oleh observer baik untuk penilaian guru maupun siswa. Dari hasil proses tersebut didapat bahwa proses keterlaksanaan pembelajaran dengan menggunakan model quick on the draw dan model picture and picture dapat terlaksana pada pertemuan pertama, kedua dan ketiga.

Pada keterlaksanaan guru dengan menggunakan model quick on the draw, pertemuan pertama mendapat hasil $80 \%$ dengan kategori baik, pada pertemuan kedua mendapat skor $90 \%$ dengan kategori sangat baik dan pertemuan ke tiga mendapat skor $100 \%$ dengan kategori sangat baik. Dan pada keterlaksanaan guru dengan menggunakan model picture and picture, pada pertemuan pertama mendapat hasil $83 \%$ dengan kategori baik, pada pertemuan kedua mendapat skor 95\%dengan kategori sangat baik dan pada pertemuan ketiga mendapat $100 \%$ dengan kategori sangat baik. Sedangkan pada keterlaksanaan siswa dengan menggunakan model quick on the draw pada pertemuan pertama mendapat skor 75\% dengan kategori cukup, pertemuan kedua mendapat skor $80 \%$ dengan kategori baik dan pertemuan ketiga mendapat $90 \%$ dengan kategori baik. Dan pada keterlaksanaan siswa dengan menggunakan model picture and picture pada pertemuan pertama mendapat skor $75 \%$ dengan kategori cukup, peertemuan kedua $88 \%$ dengan kategori baik, dan 
pertemuan ketiga mendapat skor 98\% dengan kategori baik.

Keterlaksanaan

proses

pembelajaran yang dilihat dari aktivitas guru dan siswa dengan menggunakan lembar observasi. Hasil rata-rata presentase aktivitas guru dengan menggunakan model quick on the draw sebesar $90 \%$ dengan kategori sangat baik, sedangkan dengan menggunakan model picture and picture sebesar $92,7 \%$ dan untuk rata-rata presentase aktivitas siswa dengan menggunakan model quick on the draw sebesar $81,7 \%$ dengan kategori baik, sedangkan dengan menggunakan model picture and picture sebesar $87 \%$ dengan kategori baik. Dari hasil keterlaksanaan proses pembelajaran di atas dapat di bandingan bahwa keterlaksanaan proses pembelajaran lebih menonjol dengan menggunakan model Picture and picture. Hal tersebut kemungkinan besar terjadi karena model picture and picture tersebut di anggap lebih menyenangkan di bandingkan dengan model quick on the draw, sehingga siswa sangat antusias saat menuliskan pertanyaan dan saat melaksanakan pembelajaran yang lebih bersemangat. Sehingga keterlaksanaan proses pembelajaran dengan model quick on the draw memperoleh presentase rendah karena respon siswa saat pembelajaran berlangsung dengan menggunakan model quick on the draw kurang menarik bagi siswa sehingga mendapatkan presentase di bawah model picture and picture.

\section{Kemampuan Bertanya Siswa Secara Tertulis}

Hasil analisis data pada Tabel 3.8 dan 3.9 (hal.53) yaitumenjelaskan mengenai kemampuan bertanya siswa secara tertulis yang dikelompokkanberdasarkan pertanyaan terbuka dan tertutup, setelah itu dikelompokkanberdasarkan taksonomi Bloom yang direvisi.Pertanyaan tertutup hanya memerlukan satu atau beberapa jawaban terbatasatau tertentu dan biasanya langsung tertuju pada suatu kesimpulan.
Bentukpertanyaan ini lebih tepat digunakan untuk menggali apa yang diingat oleh siswaatau pemahaman mengenai fakta-fakta. Sedangkan pertanyaan terbukamemerlukan sejumlah jawaban atau beberapa kemungkinan jawaban benar yanglebih luas dan tidak terbatas seperti pada pertanyaan tertutup. Bentuk pertanyaan terbuka dapat menuntut siswa untuk memberikan berbagai alternatif jawabanmengenai fakta, konsep ataupun prinsip yang mungkin, menyatakan alasan-alasandari suatu pendapat, menerapkan prinsip, konsep ataupun hukum pada situasibaru, meramalkan atau merumuskan hipotesis, merancang eksperimen, danmenarik kesimpulan (Arifin, dkk. 2000:149).

Pada Tabel 3.11 dan 3.12 (hal.5657) dapat dilihat, bahwa pertanyaan siswa didominasi olehpertanyaan terbuka (divergen) yaitu pada pertanyaan tertulis siswa dengan menggunakan model quick on the draw sebanyak 500 pertanyaan $(61,95 \%)$, sedangkan307 pertanyaan $(38,04 \%)$ termasuk bentuk pertanyaan tertutup dan pertanyaan tertulis siswa dengan menggunakan model picture and picture sebanyak 510 pertanyaan (56,98\%), sedangkan 385 pertanyaan $(43,01 \%)$ termasuk bentuk pertanyaan tertutup. Hal ini juga sesuai dengan hasil penelitian Septiati (2011:44) yang menunjukan bahwa pertanyaan yang banyak diajukkan oleh siswa termasuk pertanyaan terbuka yaitu sebesar $53,85 \%$.

Hal tersebutkemungkinan besar terjadi karena siswa sudah berpikir terbuka dan kritis dalammemecahkan permasalahan yang didiskusikan pada saat pembelajaran sehingga pertanyaan yang diajukan pun tidak hanya bersifat menggaliapa yang diingat oleh siswa atau pemahaman mengenai fakta-fakta tetapi siswasudah mampu mengajukan pertanyaan yang dapat memberikan berbagai alternatifjawaban mengenai fakta, konsep ataupun prinsip yang mungkin dapat menjawabpertanyaan tersebut. Dilihat dari rekapitulasi data yang 
terkumpul maka bisadisimpulkan bahwa siswa memiliki pola pikir yang masih sederhana dan belumkompleks seperti halnya orang dewasa, sehingga pertanyaan yang disampaikanpun masih dalam ruang lingkup yang sederhana.

Melihat gambaran hasil dari pertanyaan yang dianalisis pertanyaan terbuka ataupun tertutup, selanjutnya pertanyaan dikelompokkan berdasarkan dimensi proses kognitif taksonomi Bloom yang direvisi. Pertanyaan yang banyak diajukan oleh siswa secara tertulis termasuk ke dalam tingkat memahami (C2). Untuk pertanyaan tertulis yang termasuk kedalam jenjang kognitif C1dengan menggunakan model quick on the draw yaitu sebanyak 250 pertanyaan dari 807 pertanyaan yang terkumpul $(30,97 \%)$, hal ini sesuai dengan hasil penelitian Herlina (2009:49) yang menunjukkan bahwa pertanyaan yang banyak diajukkan oleh siswa termasuk kategori C2 sebanyak 450 pertanyaan yaitu sebesar $(55,76 \%)$. Sedangkan sisanya adalah C3 sebanyak 107 pertanyaan $(13,25 \%)$ sedangkan untuk C4 tidak ada siswa yang sampai pertanyaannya ke tingkat tersebut sehingga jumlahnya $0,00 \%$. Untuk pertanyaan tertulis dengan menggunakan model picture and picture siswa C2 yaitu sebanyak 475 pertanyaan (53,07\%), sedangkan sisanya adalah $\mathrm{C} 1$ 300 pertanyaan $(33,51 \%)$, C3 sebanyak 120 pertanyaan $(13,40 \%)$, dan $\mathrm{C} 4 \quad 0,00 \%$ atau tidak ada yang bertanya pada jenjang tersebut.

Berdasarkan hasil perbandingan jenjang pertanyaan dimensi proses kognitif taksonomi Bloom dari Tabel 3.10 dan 3.11 (hal.54-55) diketahui bahwa jenjang pertanyaan yang dibuat siswa bervariasi, pertanyaan tertulis tersebar mulai dari jenjang kognitif $\mathrm{C} 1, \quad \mathrm{C} 2$ dan $\mathrm{C} 3$. Pertanyaan siswa dengan menggunakan model quick on the draw yang termasuk kedalam jenjang dimensi proses kognitif C1 yaitu sebesar $30,97 \%$ pada pertanyaan tertulis dengan menggunakan model quick on the draw dan pada pertanyaan siswa dengan menggunakan model picture and picture yang termasuk kedalam jenjang dimensi kognitif $\mathrm{C} 1$ yaitu sebesar 33,51\% . Contoh pertanyaan dengan menggunakan model quick on the draw yang termasuk kedalam jenjang $\mathrm{C} 1$ yang dibuat siswa adalah siswa dengan kode S5 : "Apa yang dimaksud dengan ekosistem " dan contoh pertanyaan dengan menggunakan model Picture and picture yang termasuk kedalam jenjang $\mathrm{C} 1$ yang dibuat siswa adalah siswa dengan kode S4 : "Apa yang dimaksud dengan populasi ". Jenjang C1 merupakan jenjang menghafal yang terdiri dari mengingat dan mengenali.Kemampuan pada jenjang $\mathrm{C} 1$ ini merupakan kemampuan menarik kembali informasi yang tersimpan dalam memori jangka panjang siswa.Jenjang $\mathrm{C} 1$ kurang menuntut siswa untuk berfikir lanjut.

Jenjang C2 (memahami) pada pertanyaan tertulis dengan menggunakan model quick on the draw yang muncul sebesar 55,76\% dan 53,07\% pada pertanyaan dengan menggunakan model picture and picture. Contoh pertanyaan yang dibuat siswa dengan menggunakan model quick on the draw yang termasuk kedalam jenjang $\mathrm{C} 2$ adalah pertanyaan siswa dengan kode S22: "Apa saja yang termasuk komponen penyususn ekosistem?"dan contoh pertanyaan yang dibuat siswa dengan menggunakan model picture and picture yang termasuk kedalam jenjang $\mathrm{C} 2$ adalah pertanyaan siswa dengan kode S21: "Apa saja yang termasuk saling ketergantungan?”. Pertanyaan pada jenjang C2 meliputi tujuh proses kognitif yaitu menafsirkan, memberikan contoh, mengklasifikasikan, meringkas, menarik inferensi, membandingkan dan menjelaskan (Rustaman, 2005:156). Kemampuan pada jenjang C2 yaitu kemampuan menintegrasikan pengetahuan baru dan pengetahuan awal yang telah dimiliki siswa.Jenjang C2 merupakan jenjang pertanyaan yang paling banyak muncul pada pertanyaan siswa. 
Jenjang kognitif C3 (mengaplikasikan) pada pertanyaan dengan menggunakan model quick on the draw muncul sebesar $(13,25 \%)$ dan $(13,40 \%)$ pada pertanyaan dengan menggunakan model picture and picture. Jenjang kognitif C3 merupakan kemampuan menggunakan suatu prosedur untuk menyelesaikan tugas atau masalah. Contoh pertanyaan dengan menggunakan model quick on the draw yang dibuat siswa adalah pertanyaan siswa dengan kode S4: "sebutkan tingkat organisasi dalam ekosistem?" dan contoh pertanyaan dengan menggunakan model picture and picture yang dibuat siswa adalah pertanyaan siswa dengan kode S6: "sebutkanperbedaan rantai makanan dan jarring - jarring makanan!”. Menurut Roestiyah (2000:94) "kasus yang terkait konteks dunia nyata dapat memperlihatkan gambaran kepada siswa mengenai banyaknya macam situasi persoalan atau masalah yang dihadapi dalam kehidupan". Siswa dapat lebih membayangkan aplikasinya dalam kehidupan seharihari.Hal ini mendukung termunculkannya jenis pertanyaan $\mathrm{C} 3$.

Jenjang kognitif C4 (menganalisis) pada pertanyaan tertulis tidak ditemui. Hal ini disebabkan karena jenjang kognitif C4 merupakan jenjang yang menuntut kemampuan untuk menguraikan suatu objek kedalam unsur - unsurnya serta untuk melihat saling keterkaitan antar unsur - unsur tersebut sedangkan pada pembelajaran materi ekosistem melalui model quick on the draw dan model picture and picture kurang menuntut/menstimulus siswa untuk kemampuan tersebut.

Kemampuan siswa dalam mengajukan pertanyaan berbeda-beda, hal ini dikarenakan karakteristik siswa yang berbeda satu sama lainnya karena setiap siswa memiliki kemampuan dan pola pikir yang berbeda pula sehingga kemampuan untuk bertanya pun akan berbeda. Siswa memiliki kemampuan bertanya yang berbeda karena salah satu faktornya yaitu perbedaan karakreristik siswa, bisa juga karena potensi kognitif siswa yang berbeda satu sama lainnya. Kebiasaan siswa yang takut ditertawakan, apabila menyampaikan pendapat yang kurang tepat, itu bisa jadi salah satu faktor yang menyebabkan kemampuan bertanya siswa menjadi terhambat, oleh sebab itu seorang guru harus bisa memotivasi siswa untuk bisa melakukan proses berpikir dengan cara merangsang anak untuk bertanya.

Dari hasil penelitian yang telah dilakukan dapat dihasilkan sebuah perbandingan bahwa dengan hasil penelitian yang sudah dilakukan perbandingannya yaitu lebih banyak pertanyaan yang muncul dengan menggunakan model picture and picture dengan jumlah total semua pertanyaan dari tiga kali pertemuan yaitu 895 pertanyaan. Mengapa siswa lebih memilih model pembelajaran dengan menggunakan model picture and picture, model pembelajaran Picture and Picture adalah suatu model belajar yang menggunakan gambar dan dipasangkan atau diurutkan menjadi urutan logis. Pembelajaran ini memiliki ciri Aktif, Inovatif, Kreatif, dan Menyenangkan.Johnson dan Johnson model pembelajaran picture and picture mempunyai kelebihan dan kekurangan, yaitu:

\section{a. Kelebihan Picture and Picture}

Menurut Johonson (dalam Trianto, 2009: 12) menyatakan:

1). Guru lebih mengetahui kemampuan masing-masing siswa.

2). Melatih berpikir logis dan sistematis

3). Membantu siswa belajar berpikir berdasarkan sudut pandang suatu subjek bahasa dengan memberikan kebebasan siswa dalam praktik berpikir.

4). Mengembangkan motivasi untuk belajar yang lebih baik.

5). Siswa dilibatkan dalam perencanaan dan pengelolaan kelas.

b. Kekurangan Picture and Picture 
Menurut Johonson (dalam Trianto, 2009: 12) menyatakan:

1. Memakai banyak waktu

2. Banyak siswa yang pasif

3. Guru khawatir akan terjadi kekacauan di kelas.

4. Banyak siswa yang tidak senang apabila disuruh bekerja

5. Dibutuhkan dukungan fasilitas, alat dan biaya yang cukup memadai Untuk mengatasi kekurangan tersebut di atas, pembentukan kelompok dilakukan secara heterogen agar anak yang kurang aktif berinteraksi dengan anak yang aktif, begitu juga dengan anak yang kurang pandai dicampur dengan anak yang pandai.

\section{A. Kesimpulan}

Berdasarkan hasil penelitian mengenai Perbandingan profil bertanya siswa dengan menggunakan model quick on the draw dan model picture and picture pada sub materi ekosistem dapat diambil kesimpulan sebagai berikut :

1. Keterlaksanaan proses pembelajaran menggunakan model quick on the draw untuk aktivitas guru terlaksana 90,7\%dengan kriteriasangat baik dan dengan menggunakan model picture and picture untuk aktivitas guru terlaksana $92,7 \%$. Sedangkan untuk keterlaksanaan proses pembelajaran untuk aktivitas siswa dengan menggunakan model quick on the drawterlaksana $\quad 81,7 \% \quad$ dengan kriteria baik dan dengan menggunakan model picture and picture untuk aktivitas siswa terlaksana $87 \%$ dengan kriteria baik.

2. Jenjang pertanyaan yang paling banyak diajukan oleh siswa termasuk kedalam jenjang pertanyaan $\mathrm{C} 2$ pertanyaan tertulis dengan menggunakan model quick on the draw sebesar $55,76 \%$ dan pertanyaan tertulis dengan menggunakan model picture and picture sebesar 53,07\%.
3. Sifat pertanyaan yang paling banyak muncul pada pertanyaan tertulis dengan model quick on the drawyaitu pertanyaan terbuka sebesar $61,95 \%$ untuk pertanyaan tertulis dan $56,98 \%$ untuk pertanyaan tertulis dengan menggunakan model picture and picture. Sedangkan untuk pertanyaan tertutup siswa dengan menggunakan model quick on the draw secara tertulis sebesar $38,04 \%$ dan $43,01 \%$ dengan menggunakan model picture and picture.

Dari hasil penelitian yang telah dilakukan dapat dihasilkan sebuah perbandingan bahwa dengan hasil penelitian yang sudah dilakukan perbandingannya yaitu lebih banyak pertanyaan yang muncul dengan menggunakan model picture and picture dengan jumlah total semua pertanyaan dari tiga kali pertemuan yaitu 895 pertanyaan.

\section{DAFTAR PUSTAKA}

Anderson dan Krathwohl. 2001. A Taxonomy for Learning, Teaching, and Assessing (A Revision of Bloom's Taxonomy of Educational Objectives). Abridge Edition. Penerbit David McKay Company. New York.

Arifin, Zainal. 2012. Evaluasi Pembelajaran. PT Remaja Rosdakarya. Bandung

Ayub, N. D. 2006. Belajar Teori Belajar Dalam Pembelajaran. Pekanbaru.Universitas Riau.

Aziz, H. 2008. IPA Biologi. Edisi 2. Jakarta

Bundu, Patta. 2006. Penilaian Keterampilan Proses Dan Sikap Ilmiah. Jakarta.Direktorat Jendral Pendidikan Tinggi

Campbell, Neil A., Reece, dan Mitchell. 2004. Biologi Edisi Kelima-Jilid II1. Jakarta: Penerbit Erlangga

Fathurrohman, Pupuh \& Sutikno. 2000. Strategi Belajar Mengajar. PT Refika Aditama. Bandung. 
Fitriansyah. 2011. Upaya Meningkatkan Hasil Belajar Matematika Siswa SMP Negeri 3 Malang Melalui Strategi Pembelajaran Quick On The Draw. Jurnal pendidikan matematika.

Ginnis, Paul.2008. Trik dan Taktik Mengajar. Indonesia. PT Indeks. Hamdani. 2010. Strategi Belajar Mengajar. Bandung: Pustaka Setia.

Hasibun, J.J dan Moedjiono. 2008. Proses belajar mengajar. Bandung: PT Remaja Rosdakarya

Huda. Miftahul. 2014. Model-Model Pengajaran dan Pembelajaran. Pustaka Pelajar. Yogyakarta

Istarani, 2011. 58 Model Pembelajaran Inovatif (Referensi Guru Dalam Menentukan Model Pembelajaran). Medan : Media Persada.

Irwan. 2003. IPA Biologi 1. Jakarta: Eisis

Kimball John W. 2002. Biologi Edisi Kelima-Jilid II. Jakarta: Erlangga

Khoiri.2007. IPA Biologi 1. Jakarta: Eisis

Kusmawati, R. dewi. 2010. Profil Pertanyaan Siswa SMA Pada Sub Konsep Pencemaran Lingkungan Melalui Diskusi Kelompok Terbimbing Tutor Sebaya. Skripsi Pada FMIPA UPI Bandung: Tidak Diterbitkan

Kurnadi, K.A. 2011. Dasar-Dasar Anatomi Dan Fisiologi Tubuh Manusia. Bandung:FPMIPA UPI

Lampiran Peraturan Menteri Pendidikan dan Kebudayaan Republik Indonesia Nomor 65 Tahun 2013 Tentang Standar Proses Pendidikan Dasar dan Menengah.

Mulyana, Aina. 2012. Kemampuan Bertanya Pada Siswa. Dalam http://ainamulyana.blogspot.com/2 012/02/kemampuan-bertanya-padasiswa.html [diakses tanggal 29 februari 2016].

Permendiknas.2006. Standar Kompetensi Lulusan Untuk Satuan Pendidikan Dasar dan Menengah. [Online] Tersedia: http://www.pustaka.ut.ac.id/dev25/ pdfprosiding2/fmipa201146.pdf (10 januari 2016)

Purwanto, N. 2008.Prinsip-Prinsip dan Teknik Evaluasi Pengajaran. Penerbit Remaja Rosdakarya. Bandung.

Rustaman, Nuryani. 2005. Strategi Belajar Mengajar Biologi. Malang: Universitas Negeri Malang

Rosmaini S,dkk. 2012. Penerapan Model Pembelajaran Kooperatif Dengan modelQuick On The Draw Untuk Meningkatkan Sikap Ilmiah Dan Hasil Belajar Biologi Siswa Kelas Xi Ipa Sma Negeri 2 Kuantan Hilir Jurnal Biogenesis, Vol. 9, Nomor 1, Juli 2012

Sagala, Saeful. 2003. Konsep Dan Makna Pembelajaran. Bandung: Alfabeta

Saktiyono. 2008. IPA Biologi 1. Jakarta: Esis

Septiati, 2011.Profil Kemampuan Bertanya Dan Berkomunikasi Siswa Melalui Metode Field Trip Pada Konsep Pencemaran Lingkungan.Skripsi Universitas Pendidikan Indonesia.Bandung : Tidak Diterbitkan

Slameto. 2003. Belajar dan factor-factor yang mempengaruhinya. Jakarta: PT Rineka Cipta

Subana. 2000. Statistik pendidikan. Jakarta : PT. Pustaka Setia

Sudarman, dkk.2009. Ilmu Pendidikan. Bandung: PT Remaja Rosdakarya.

Sudjana, N. 2008.Penilaian Hasil Proses Belajar Mengajar. Bandung : Remaja Rosdakarya

Sugiyono. 2013. Metode Penelitian Pendidikan Kualitatif, Kuantitatif dan R\&D. Bandung : Alfabeta

Sukardi. 2011. Metodologi penelitian pendidikan. Jakarta: PT Bumi Aksara

Sumarwan.2007. IPA Biologi 1. Jakarta: Eisis

Supriadie Dan Darmawan. 2012. Komunikasi pembelajaran. Bandung: PT Remaja Rosdakarya 
Suprijono. Agus. 2013. Cooperative Learning. Pustaka Pelajar. Yogyakarta

Sudjana.2005. Metoda statistika.Bandung : Tarsito

Sugiyono.2007. Metode Penelitian Administrasi.Bandung: Alfabeta.

Syaban. 2009. Menumbuhkembangkan daya dan disposisi matematis siswa sekolah menengah atas melalui pembelajaran investigasi. Education,3(2), [Online] Tersedia di:http://file.upi.edu/Direktori/JUR NAL/EDUCATIONIST/Vol. III No. 2Juli 2009 Mumun Syaban.pdf [09 januari 2016]

Syah, Muhibbin. 1995. Psikologi Pendidikan. Bandung: Rosda.

Tafsir, Ahmad dkk. 2009. Pengembangan Wawasan Profesi Guru. Bandung: Fakultas Tarbiyah Dan Keguruan Universitas Islam Negeri Sunan Gunung Djati.

Trianto. 2009. Model - model pembelajaran inovatif berorientasi konstruktivisik prestasi pustaka:Jakarta

Widodo, A. 2006.Peningkatan Kemampuan Siswa SD untuk Mengajukan Pertanyaan Produktif. Jurnal Pendidikan dan Pembelajaran. 4(2). 139-142.

Widodo, A. 2006.Profil Pertanyaan Guru dan Siswa dalam Pembelajaran Sains. Jurnal Pendidikan dan Pembelajaran. 4(2).139-148. 